\title{
An integrated process for forming manufacturing technology acquisition decisions
}

\section{Tim Baines}

\section{Introduction}

Technology affects competitive advantage and industry structure, and can worsen as well as improve a firm's competitive position (Porter, 1985). Technologies, be they product or process based, provide the principal and often only route to differentiating products, reducing costs and providing new business opportunities (Floyd, 1997). As a consequence, competent technology management is frequently a crucial element in the success of a firm (Skinner, 1985). The research in this paper has focused on one element of technology management, namely, the process of manufacturing technology acquisition from the perspective of the company that will actually use the technology.

A manufacturing technology is typically a production machine or facility, and every manufacturing technology in operation has been acquired through some form of explicit or implicit decision process. This process is typically complex with a wide range of potential characteristics. For example, this process could be initiated in response to either a business need or alternatively an awareness of a new technological capability. It could include a detailed and analytical review of the business and technology, or be largely based around the judgement of a few senior personnel. It could involve a range of people, such as the vendors and eventual users, or simply be prescribed by a group of external consultants. It could be documented as an organisational procedure, or only exist as a form of company practice and know-how. Irrespective, however, of these characteristics, the success of the resultant technology is largely determined by this process, and a poor decision can leave production overly dependent on a few items of complex equipment.

Most business textbooks note the importance of technology, but few offer specific guidance to managers (Berry and Taggart, 1998). In a similar manner, much research has investigated specific aspects of the manufacturing technology acquisition process, but the practitioner still lacks a complete guide on how to interlink and apply the relevant contributions. Therefore, the research described in this paper has set out to bring together theory and practice to provide a comprehensive, generic and integrated manufacturing technology acquisition process that is relevant to the needs of practitioners. The research methodology has followed four distinct phases. First, to establish the basic form that a process can take, an exploration of practice was carried out in a company that is highly dependent on manufacturing technologies for product differentiation. The second phase of the research then compared this industrial process to theoretical constructs in the technology management literature, as well as parallel literature on topics such as product and knowledge acquisitions. In this way a pilot process was defined. The third phase of the research was to refine this process through a survey of practices of 28 other organisations. This enabled the pilot process to be refined and then incorporated into a handbook for practitioners. The final phase of the research was then to assess the complete process through an in-depth and extended case study in a UK-based manufacturing company.

This paper presents the finalised manufacturing technology acquisition process. This is a rational and formalised process, having nine steps ranging from technology profiling to post-investment auditing. Each step is a unique activity, and is defined in terms of purpose, how it is carried out, who is involved, etc. The process is biased towards the practitioner, and is targeted at the engineer within the host organisation. The case study based assessment showed this process to provide a logical and complete method of managing manufacturing technology acquisitions.

This paper is structured to first provide a background to this topic, along with an overview of previous research. The research aim and method are then presented in detail. The manufacturing technology acquisition process is then 
summarised, leading to the case study assessment of the process in practice, and finally conclusions and future work.

\section{Background and research context}

A manufacturing technology can be a machine, an item of equipment or an innovative production method. Such technologies can form the essence of an organisation's core competences (Quinn and Hilmer, 1994). Indeed many cases exist where a new manufacturing technology has enabled leading edge product technology, and this in turn has led to business success. Key examples include Kodak, who developed an antistatic coating technology for their microfilm that would not attract dust, and similarly Gillette, who worked to develop laser spot technology for their "Sensor" razor (Bowers and Christensen, 1995). Likewise, leading manufacturing technology enabled Pilkington to launch the world's first self-cleaning glass (Floyd, 1997; Twiss, 1986).

In contrast, the wrong technology, or even the right technology poorly implemented, can have dire consequences. Manufacturing technology acquisitions usually mean high capital investment, and often leave the host organisation overly dependent on a few pieces of extremely complex equipment. For example, in 1971, the failure to successfully apply carbon fibre technology to RB211 fan blades was one of the factors that contributed to the collapse of RollsRoyce (Floyd, 1997).

Manufacturing technology acquisition can be thought of as the identification, selection, transfer and implementation of technological solutions to deliver improved manufacturing capabilities for increased business performance. This is a decision process; a sequence of activities that lead to the formation of a decision. A technology acquisition process almost always exists in a manufacturing company, though it is not necessarily structured and formalised. This process view of technology management is gaining wide acceptance within the literature (Chatterji, 1996).

A variety of authors have made significant contributions to the necessary form of a manufacturing technology acquisition process. For example, Durrani et al. (1998) provide a generic formalisation of the process from the stage of establishing market-place requirements, through to forming the technology acquisition decision. Similar structures are provided by Anderson et al. (1997), Chiesa and Manzini (1998), Floyd (1997), Frohlich (1998), Gerwin and Kolodny (1992), Goodman and Lawless (1994), Hax and No (1992), Preece (1989) and Twiss (1986). Other authors are less generic, preferring instead to pay their attention to the acquisition of specific technology types, such as Luong (1998), who has concentrated on computer integrated technologies.

When this literature base is investigated in some depth a number of inconsistencies are apparent. First, the processes offered are rarely aligned in terms of both the number and the purpose of the decision steps. For example, Hax and No (1992) see this as an eight-stage process with interlinkages into the strategic planning of the organisation, whereas Zavecz (1997) views the process simply as four stages of analysis leading to equipment purchase. Second, beliefs differ as to the point at which the technology acquisition process should begin. A common view is that acquisition is driven from strategy (Chiesa and Manzini, 1998; Gerwin and Kolodny, 1992; Goodman and Lawless, 1994; Hax and No, 1992), while others argue that a project may also commence through awareness of emerging technology capabilities (Cohn, 1980; Howells,1997; Mowever and Rosenberg, 1979; Petroni, 1985). A third contention arises around where a process should end. Most consider the final stage to be generally concerned with the decision to introduce the technology into the host organisation. However, authors such as Farrukh et al. (2000), Frohlich (1998), Gregory et al. (1996) and Preece (1989) see the final stages to include activities such as technology introduction, protection and control. This correlates with the somewhat parallel work of Chatterji (1996) and Ranft and Lord (2002), who view this process as finding, acquiring and internalising technical knowledge.

In addition to the structure of the overall process, the depth and breadth of analysis in each stage of the process is also seen differently. At one level, researchers like Gregory et al. (1996) deal with an overarching technology management framework and so only treat acquisition as a sub-process. At a much lower level, there are many authors, such as Baines et al. (1999), Fine and Whitney (1996), Phaal et al. (2003) and Punniyamoorthy and Ragavan (2003), who deal entirely and in depth with individual topics such as technology road-mapping, technology sourcing, 
and technology selection. Such research provides the practitioner with a wealth of decision aids, and so a freedom to deal with technology acquisition issues at many levels. Nevertheless, it would be helpful if a normalitive process could be defined. Such a process would need to strike a balance between the level of analysis carried out as part of the process, and linkages with existing analytical tools and techniques.

In summary, existing research provides key strands of knowledge, which if appropriately combined, should provide the foundation for a complete and balanced manufacturing technology acquisition process. Unfortunately, many of these strands have yet to be rigorously evaluated and confirmed. Development would therefore need to incorporate considerable assessment and reflection of industrial practice, both to refine the scope and structure, and also to ensure the relevance and reliability of the resultant process.

\section{Research aim and methodology}

\section{The research aim and methodology overview}

The aim of the research was to form a complete and interlinked process of manufacturing technology acquisition that is relevant to the needs of practicing engineers and managers. To achieve this, an indication was first needed of the overall and general structure that such a process should take. As some inconsistencies exist in the literature, it was felt necessary to begin by exploring the form and nature of processes followed in practice. This work was carried out and provided a basic process structure. This structure was then developed by incorporating and integrating established theory and ideas apparent in the literature, and in this way a pilot process was formed.

Relevance across industry sectors was considered essential. To achieve this, practices from many sectors of industry were reviewed, and wherever possible used to develop the pilot process further. Finally, the reliability of the new manufacturing technology acquisition process needed to be ensured. The most revealing assessment was felt to be an in-depth, extended, and rigorous test of the process in practice. This completed the research programme, which can be summarised in terms of the following four objectives:

1. Capture the form and structure of a manufacturing technology acquisition process used in practice.

2. Expand the initial process to incorporate associated theory and from this develop a pilot process.

3. Refine this pilot process against the leading practices followed across industry.

4. Assess the new process through in-depth and rigorous practical application.

These objectives naturally led to a four-phase research programme, which is described as follows.

\section{Phase 1: exploring technology acquisition processes applied in practice}

This research set out to improve industrial practice. To achieve this it was important to establish the form that a typical contemporary process could take. An example of leading practice was sought, and this was provided through collaboration with an aero-engine manufacturer. This company is highly dependent on the capabilities of its manufacturing technologies, and hence likely to demonstrate competent manufacturing technology acquisition processes. The challenge then became one of capturing industrial practice, but doing so without causing any corruption that could occur by entering the company with a set of preconceived ideas as to the form that such a process should take.

The technology acquisition process at the collaborator was investigated using a case study approach adopted from Yin (1994). The case study constructs were expanded to include the continuous interplay among the ideas of context, as well as the content and process of a decision (Whipp et al., 1991). As technology acquisition is a decision process, a broad and abstract proposition of the structure of decision processes was adopted from Mintzberg et al. (1976). The resulting research method is described by Baines and Darlow (2000). Using this approach, seven technology projects were investigated within the collaborator. In each case, practitioners were asked to describe how they went about the acquisition process, including how the project was initiated, the steps they went through, who was involved and the eventual outcome of the process. The results of these cases were then combined. 
Using this approach a map of contemporary practice followed by the collaborator was generated. The principal steps in this process were: identify need/opportunity; search, evaluate and select technology; implement and review. This map showed that in the case of the collaborator, the early stages of an acquisition project are quite fluid, whereas the later stages are highly proceduralised. A clear example of this was in the stages of formation of a business case and technology implementation where company procedures existed. The nature of the activities at each stage also varied significantly based on the maturity or life cycle of technologies. For example, where a technology was simply a like-for-like replacement for an existing and worn out machine, the assessment of possible risks was significantly less involved than a situation where a new and emergent technology was being considered.

\section{Phase 2: formation of the formalised pilot process}

The outcome of the exploration of industrial practice provided a basis on which to review and align contemporary technology management thinking, and in this way form the pilot process. The literature provides a variety of suggestions about the process stages, as highlighted earlier, along with ideas, techniques and tools associated with each stage. The challenge was to integrate relevant contributions with the process structure, but to do so in a way that provided a workable methodology. As described below, analysis was first conducted to break down the process into a number of stages, and then to develop the content of each stage.

The exploration of industry practice has indicated that the process form is in some way dependent on technology maturity. The literature provides some helpful insights to the mechanisms that may exist. Floyd (1997) suggests that there are four phases of technology maturity or life cycle, namely, base, key, pacing and emerging. Similarly, Popper and Buskirk (1992) class technologies as either cutting edge, advanced, mainstream, mature, or declining. In general, if a technology is mature, there is usually less risk associated with the acquisition, and the process is relatively simple. Within this category fall, for example, technologies that are duplicates and replacements of existing machines. Alternatively, technologies can be very new or emergent, they have never been used in practice before, and their eventual competitive impact may be difficult to judge. These emergent technologies may take a number of years to develop to a point where they can be reliably used in production, and they are often associated with potentially high benefits but similarly high risk. There are also intermediate technologies; these may be new to the business and sector though used regularly in other industries. Tools for tracking and planning the development, maturity and decline of technologies have been investigated by Abernathy and Utterback (1978), Frohlich (1998), Gregory et al. (1996), Kim (2003), Popper and Buskirk (1992) and Swamidass (1987).

The exploration of industry practice had also indicated that the process form is in some way dependent on the means in which a project is initiated. Technology can be introduced into an organisation in two principal streams of technology push and demand pull (Cohn, 1980; Howells, 1997; Mowever and Rosenberg, 1979; Petroni, 1985). Demand pull occurs where business and market needs such as cost reduction, quality enhancement or new product development drive the search for manufacturing technologies. Technology push occurs where a company becomes aware of a technology and looks for exploitation opportunities. This concept, however, is not without contention as some authors, such as Howells (1997), prefer the notion of use, need and intended use. Indeed, instances of a technology being purely by either technology push or demand pull may be rare. A project may commence with clearly defined need, but once operational, new opportunities may be apparent to exploit the new technological capabilities more widely throughout the organisation.

Finally, the exploration of industry practice had shown that a complete process of manufacturing technology acquisition needs to include some form of review. Figure 1 shows the interactions between existing company standards, conventions and procedures during the case studies carried out in phase 1 . As demonstrated here, some form of post-investment audit may already be in place within an organisation. This understanding clarifies the point at which the process should be considered complete, and when taken collectively with an understanding of the mechanisms of technology introduction discussed above helps to determine the process scope. This scope was then contrasted against the existing processes introduced earlier in this paper (Chiesa and Manzini, 1998, Frohlich, 1998; Gerwin and Kolodny, 1992; Goodman and Lawless, 1994; Gregory et al., 1996; Hax and No, 1992; Preece, 1989), and 
through reviewing these contributions nine process stages were defined. These are explained in detail later in this paper.

The analytical content of each stage was then developed. Again, Figure 1 provides a summary of the more popular ideas, tools and techniques featured in this development. As illustrated, the earlier stages of a process complement research concerned with technology planning, such as "technology forecasting" (Twiss, 1986), "technology tracking" (Floyd, 1997), "technology road mapping" (Barker and Smith, 1995; Phaal et al., 2003). Other relevant work is research that looks at how knowledge about technologies is acquired by an organisation. Typical examples include alliances (Lambe and Spekman, 1997), inter-firm networks and collaborations (Gomes-Casseres, 1994; Grandori and Soda, 1995; Hakannson, 1990; Millson et al., 1996). The intermediate stages of the process deal with search, evaluate and select. Research on networks and alliances, and the wider aspect of knowledge management, fits into this stage as a means of searching for technological solutions. So too is work on technology source assessment and selection process (Baines et al., 1999; Chatterji, 1996). The evaluation activity brings in the notion of fit with the business or competitive strategy of the host organisation (Drejer and Sorensen, 2002; Hamel and Heene, 1994). Finally, selection of alternatives can be supported by research into decision modelling (Baines and Kay, 2002; Robinson, 1994), and investment appraisal techniques (Twiss, 1986). The final stage of the process deals with technology implementation and review. Here, relevant work includes quality improvement techniques (Ealey, 1992; Gunter, 1989; Pearn and Chen, 1999), and techniques of planning, measurements and benchmarking (Floyd, 1997). Taken collectively these contributions enable the pilot process to be developed.

\section{Phase 3: refinement of the pilot process against leading practices}

Work then set out to ensure that the pilot process captured as far as possible leading industrial practice, and this was carried out by contrasting the pilot process with the practices in a wide range of industries. The research design adopted was semi-structured interviews based around a questionnaire. Questions were structured to assess whether the pilot process reflected leading industrial practice, and the form it should take to be most useful to practitioners. In all, 28 companies were visited by the research team. A general overview of the companies studied is given in Table I. Further details about these companies are available from the author.

On completion of this research the acquisition process was refined. In particular, the structure of the push/pull streams was amended, and much greater detail was added to each of the stages. In addition, a variety of associated tools and techniques were identified. The complete methodology was then encapsulated in a practitioner handbook.

\section{Phase 4: assessment of the process through industrial application}

The final phase of the research was to assess the new process through application to a real project. Our objective was to assess whether the technology acquisition process is a valuable aid to practitioners. To do this we need to understand how the prescribed process affected the actions and decisions involved in a real technology acquisition project. Our earlier work in phase 1 demonstrated that these interactions are complex and difficult to describe. Therefore, in order to obtain a rich understanding of how well the process worked, a case study based research approach was again chosen. The case study design was again based on the work of Yin (1994). In this case, the proposition was the refined process which was the outcome of phase 3 of the research programme.

An important consideration in designing the study was the choice of company at which to apply the process. Our preference was for a longitudinal study where the acquisition process would be applied throughout the life cycle of a manufacturing technology project. During this time, the research team would adopt the role of facilitators following the model demonstrated by Platts and Gregory (1990). An alternative collaborator to that used to develop the process was then sought and recruited to this work. This company is a large automotive manufacturer with several plants in the United Kingdom. One plant was chosen to participate in this work, and within this, one major project identified as a candidate for the case study. The topic of the case study was the introduction of flexible CNC machining centres used in the production of automotive engine cylinder heads. These machines were sought as an 
alternative to the traditional transfer line approach to manufacture, providing greater flexibility to produce cylinder heads for a wider range of products.

In this study the approach adopted was to follow, in parallel, the traditional acquisition process practiced by the engineers, along with the pilot acquisition process. In this way, the team would develop a thorough understanding of where and when the prescribed process intervened or contradicted the actions of the practitioners. Furthermore, this approach provided the collaborator with the reassurances they needed to participate in this study, as the targeted technology investment was valued in the order of several million dollars.

Three sets of criteria were used to assess the prescribed acquisition process against the objective of this study. These performance criteria were adopted from the work of Platts (1993), and were:

1. Feasibility. Can the process be applied?

2. Usability. Is the process easy to apply?

3. Utility. Did the process provide a useful output?

Using these performance criteria a set of associated indicators were identified. These criteria were recorded throughout the project, both by the facilitator and through a diary kept by the engineers themselves. The results of this case study are presented in the final section of this paper, with the following section first providing an overview of the process.

\section{The process approach to manufacturing technology acquisition}

\section{Overview of structure}

This process is principally for project managers and engineers who are responsible for acquiring, evaluating, implementing and monitoring new manufacturing technology. The complete process is described in nine steps, these are summarised in Figure 2, and explained in greater detail in the Appendix. In some cases the step is broken down into two or more tasks to enable a greater depth of analysis. Each step in the process is described consistently in terms of what (the purpose), why (the justification), how (the mechanism), who (the people involved), outcome (the deliverables) and risks (the issues that may arise from not carrying out the step properly). In addition to the Appendix, a handbook has been developed that captures the whole process and presents this along with associated tools and techniques. This is available from the author.

Within the process, a step-wise sequence is implied in this process but not enforced. An inexperienced user working on a new project may choose to follow the process step by step, whereas an experienced engineer may choose to use the process as simply a checklist. This also enables the process to be used for both emergent technologies, where a step might be followed in full, and mature technologies when once again the process may simply be used as a checklist. At five points in the process, decision gates are given. Each gate contains a set of conditions that should exist by that stage in the process, if these conditions are not met acquisition should not proceed.

Each step in the manufacturing technology acquisition process is carried out by one or more people who act out specific roles, as illustrated in Table II. For example, throughout the process a person has to be appointed as the project leader. This, however, is a generic role that is specifically defined for this process, and may not necessarily be the same as a person's job title. In a smaller project, one person might take on a number of roles, while in a larger project several people may take on one role.

The process can be entered at two points. Step 1 deals with technology push and is intended to be an ongoing activity to heighten awareness of technology opportunities within the host organisation. This may lead to the stimulation of an acquisition project, and so step 2 of the process would commence. Alternatively, a user may join the process with a business need already established as is the case with demand pull, and in this situation the process would commence at step 2. 
Step 1: technology profiling (start for push stream)

This is the first step of the process, and unlike all other steps, is intended to be an ongoing activity within the organisation rather than be project specific. To enable technology push, the company is encouraged to continually search for new manufacturing technologies. The technologies can be identified from a variety of sources, from university and laboratory research, to equipment vendors (Floyd, 1997). Undoubtedly, success depends on good networks with technology developers. Useful technical knowledge may arise from both formal and informal networks, and channels both within and outside the organisation (Chatterji, 1996). This may be enabled by techniques that track the evolution of technologies, for example, "technology tracking" (Floyd, 1997), "technology forecasting" (Twiss, 1986; Twiss and Goodridge, 1989), along with a general understanding of patterns of industrial innovation (Abernathy and Utterback, 1978). In particular, "technology road mapping" (Barker and Smith, 1995; Phaal et al., 2003) is a valuable aid in the development of a technology plan to achieve commercial goal. To accommodate such techniques, the process has two separate tasks, namely: maintain technology portfolio and then search for technology applications. The search for technology application is a natural progression from the knowledge represented by a portfolio and involves, for example, operating workshops internally in an attempt to identify opportunities to exploit techniques. The outcome of this continual search will be occasions when some match is apparent between the capabilities of a new technology and challenges within product manufacture. When this occurs, step 2 of the process can commence.

\section{Step 2: establish requirements of technology}

Our intention is that this step should couple both streams of technology acquisition. It may be entered either as a consequence of step 1, which has formalised technology push, or alternatively it may be executed as the first step in the demand pull stream. In the case of demand pull, this need may materialise from a shop floor problem, or may be generated through a more strategic initiative such as new product introduction (Arnold and Floyd, 1997). In either case, the outcome is intended to be a clarification of how a technology will need to perform to benefit the business host. To achieve this, we propose three tasks. First comes outline competitive need, where a general statement is formed about the type of improvement sought. The second task is to bring together a project team. Within this project team, the third step is addressed which is to fully clarify the competitive need. Our intention is that this final task will express the requirements on the technology in terms of competitive needs of the organisation.

\section{Step 3: find a technological solution}

Once the requirements of a technology are known, a search may begin to identify a technology with the necessary capabilities. If the project commenced through a technology push initiative, then this step may simply be a confirmation exercise. Alternatively, it may require a revisit to many of the methods and techniques described in the first step of this process. The purpose being to identify the technology "type", though not necessarily the source, which is likely to fulfil the competitive need identified in step 2 of the process.

This step has been divided into two tasks, first comes search for technologies and this is followed by select technology. Undoubtedly, the nature of the search activity will be dependent on technology maturity (Floyd, 1997), and again make use of knowledge search techniques and networks (Chatterji, 1996). At the close of this step of the process, the form of technological solution and some possible alternatives will have been established.

\section{Step 4: form outline business case}

The purpose of this step is to formally define the potential fit between technology capabilities and competitive need, and on this basis decide whether to continue with the project. Organisations may choose to carry out this initial evaluation from various perspectives. For example, the technology can be considered relative to the core competences, or fit with the business or competitive strategy of the host organisation (Drejer and Sorensen, 2002; Hamel and Heene, 1994). Some consideration of alternatives can be made using decision modelling (Cooke and Slack, 1991) or modelling based on simulation techniques (Baines and Kay, 2002; Robinson, 1994). Here, the first formal decision point is reached, Gate 1. Present outline case to gain project approval. As with all gates in this process, the project should only proceed if approval is gained. 
Step 5: choose technology source

Technology acquisition is not synonymous with purchasing. The technology may be sourced internally or externally to an organisation (Baines et al., 1999). In addition, a helpful distinction needs to be drawn between the ownership of knowledge and the ownership of assets (Quinn and Hilmer, 1994). Here, depending on the project scale and ambition, opportunities may be provided through alliances (Lambe and Spekman, 1997), inter-firm networks and collaborations (Gomes-Casseres, 1994; Grandori and Soda, 1995; Hakannson, 1990; Millson et al., 1996) with other organisations; which may help to reinforce and sustain the advantages offered by a technology.

The technology sourcing decision is itself complex, and failure to manage this process can be problematic (Chatterji, 1996). Collaboration and strategic alliances can provide important opportunities, but demand specific management approaches (Cagliano et al., 2000). Factors such as the maturity of the technology under consideration, the importance of the technology to the business, and the characteristics of the supply base all need to be considered when identifying the technology source.

Here there are two tasks, first comes search for technology sources, which is followed by select technology source. To support this activity, various tools are available that guide the source assessment and selection process, such as Baines et al. (1999) and Chatterji (1996). These can be complemented by an understanding of the risks and benefits of internal and external sourcing, such as loss of control over knowledge and skills (Armistead and Mapes, 1993; Quinn and Hilmer, 1994; Jennings, 1997; Mclvor, 2000). After this, the second formal decision point is reached with Gate 2. Choose supplier(s).

\section{Step 6: demonstrate technology}

This step is concerned with development of the technology to a point that is capable of confirming that the original business case is valid. In the case of a technology at an early stage of development, a dedicated development facility may be constructed to evaluate the technology on simple test pieces. If successful, the unit may then be tried with successively larger and more complex components. At the other extreme, a mature technology embodied in a piece of equipment can usually be demonstrated or witness tested at the supplier (Harrold, 2003). A formal decision point again follows, Gate 3. Confirm technology capabilities.

\section{Step 7: confirm business case}

The business case then needs to be fully developed and evaluated. This is a much more detailed consideration of a technology's capabilities and its fit with business need. Many of the tools and techniques used in step 4 will again be employed. The emphasis is now on proceeding with the technology acquisition, and so all the normal financial appraisals will be carried out, such as discounted cash flow (Twiss, 1986). An insight into risks, such as unforeseen obsolescence and determination, can be gained by understanding technology patterns as illustrated by concepts such as the S-curve (Kim, 2003; Swamidass, 1987). The economic argument becomes more complex when considering how a technology may enhance an organisation's competitive position (Ramasesh and Jayakumar, 1993). Here, it is helpful to consider integrated models for learning and evaluation of technologies (Mohanty and Deshmukh, 1998). The process does not advocate a single approach, but rather anticipates the application of standard company financial practice.

\section{Step 8: implement technology}

Once the business case has been approved, technology implementation can proceed. There are many issues to consider within implementation. Here, we have attempted to outline just the main activities in the step, therefore, just two tasks are suggested. First comes create implementation plan. This project plan should be broad, covering issues such as: health and safety, services, installation, training, logistics, preparation of facilities. An instructive review of project management technologies is provided by Maylor (2001). The second task is the execution of the plan and is termed installation and pre-production preparation trials, which covers issues such as machine trials and handover. A final process decision point is then reached at, Gate 5. Commission and handover to manufacturing. Here, quality improvement techniques (Ealey, 1992), can help engineers to refine equipment capability prior to 
production, along with statistical tools such as Cpk (Gunter, 1989; Pearn and Chen, 1999) which can be used to measure process capability.

\section{Step 9: post-investment audit}

Here, the aim of this final step is to help the organisation learn through its experience of technology acquisition for the benefit for other similar implementations. Here, techniques of measurements and benchmarking (Floyd, 1997) can help to confirm the relevant success of a technology. This information can then be fed back into the organisation to improve procedures such as investment appraisal.

\section{Results of applying the process approach to manufacturing technology acquisition}

The process was followed throughout a large and complex technology acquisition project which has lasted for almost one year. It has been extremely difficult to measure objectively whether the approach has been successful, and therefore subjective assessment from the management and engineers involved within the project has been relied on. Against the assessment criteria of feasibility (can the process be applied?), it was found that there were no major problems following the process. The process handbook uses a two page approach to describe each process step, and this was particularly well received and held in high regard compared to traditional textbook and company procedure documentation. In terms of usability (is the process easy to apply?), the principal problems occurred with "installation and pre-production planning". Here, the tools necessary to determine whether the capability of a machine meets expectations are extremely expensive in terms of time and resources. This is particularly the case where a new technology is being developed for a new product line (as was the case in the study). In this situation, the materials and components which are required to test the new technology may have to be specially prepared. This occurs when the production facility that would normally produce these may itself not have reached capability, and scheduling constraints mean that testing of the new technology can wait no longer. There is a whole range of such issues associated with this technology commissioning, and attempting to address these in the acquisition process would distort the balance and emphasis of the methodology. Rather, this case has influenced the direction of our own research, as we are now engaged with the collaborator in a major study to produce a sub-process and handbook for the installation technology acceptance. This will dovetail and complement the technology acquisition process described in this paper.

The final assessment criterion was utility (did the process provide a good output?). In the study, the engineers found that the process was particularly helpful for rationalising problems and data. The weaker areas were the earlier steps, especially those concerned with technology push. A concern was that although the concept of technology portfolio was very valid, the method of applying this (e.g. company intranet) would need to be assessed over a longer term. To some extent, our investigation was constrained by the nature of the study, as some ideas about a suitable technology had already been informally proposed when the case commenced. Similarly, there were also concerns with the commissioning activities as mentioned earlier. In all, the engineers were keen to keep using the handbook. It is also worth mentioning that the earlier collaborator, who did not participate in this second study, is also adopting this process.

On the basis of the case study, we are satisfied that the process for technology acquisition provides a logical and interrelated method for structuring a complete project. Opportunities for further development of research are apparent in the earlier stages of the process, and in particular the sub-process concerned with commissioning of a technology.

\section{Concluding remarks}

This paper has described the formation of a process for manufacturing technology acquisition. The research has brought together leading industrial practices with views held in the literature. The result is a process that leads the practitioner from assessing both business need and technology opportunities, through to reviewing the success of a technology decision. 
The greatest impact of this research will be to practitioners. Most manufacturing companies acquire their own manufacturing technologies. This is a frequent and ongoing activity within industry, yet the managers and engineers who carryout this process have few guides. Previously they had to overly rely on experience, intuition and institutionalised practices. The process, which is the product of our research, should be a valuable aid to these people.

As to the future challenges, the earlier stages of the acquisition process are likely to evolve, especially as new and alternative methods of knowledge acquisition mature and gain acceptance. Adoption, however, will be dependent on immediate and obvious relevance to the practitioner. Throughout this research we have constantly been made aware that practitioners are often maverick in their behaviour, and may only consider consulting scientific techniques when they encounter a severe obstacle. They will, however, embrace an opportunity to visit a trade-fair. These behaviours need to be better understood and may be exploited.

A second challenge lies in the technology acceptance sub-process concerned with installation and production trailing of a technology. This is likely to be more of a practical problem, for example, providing guidance to the engineer on the number and form of production tests required to commission production equipment. In the case of the second collaborator, the company had adopted a blanket policy of trialling all new machines with 50 components which, on occasions, could become extremely expensive. Better methods of conducting trials do already exist, but the challenge is to develop an integrated approach that links acceptance issues firmly into the technology acquisition process wherever necessary.

Our final thoughts on future work are that this process will benefit from continued and cross-sectoral studies. These will help to further ensure that the process is generic, and will most likely lead to eventual refinements in the detail of how steps are executed. To this end, we will now go ahead with publishing a handbook describing the process, and subsequently monitor and report on its uptake by practitioners.

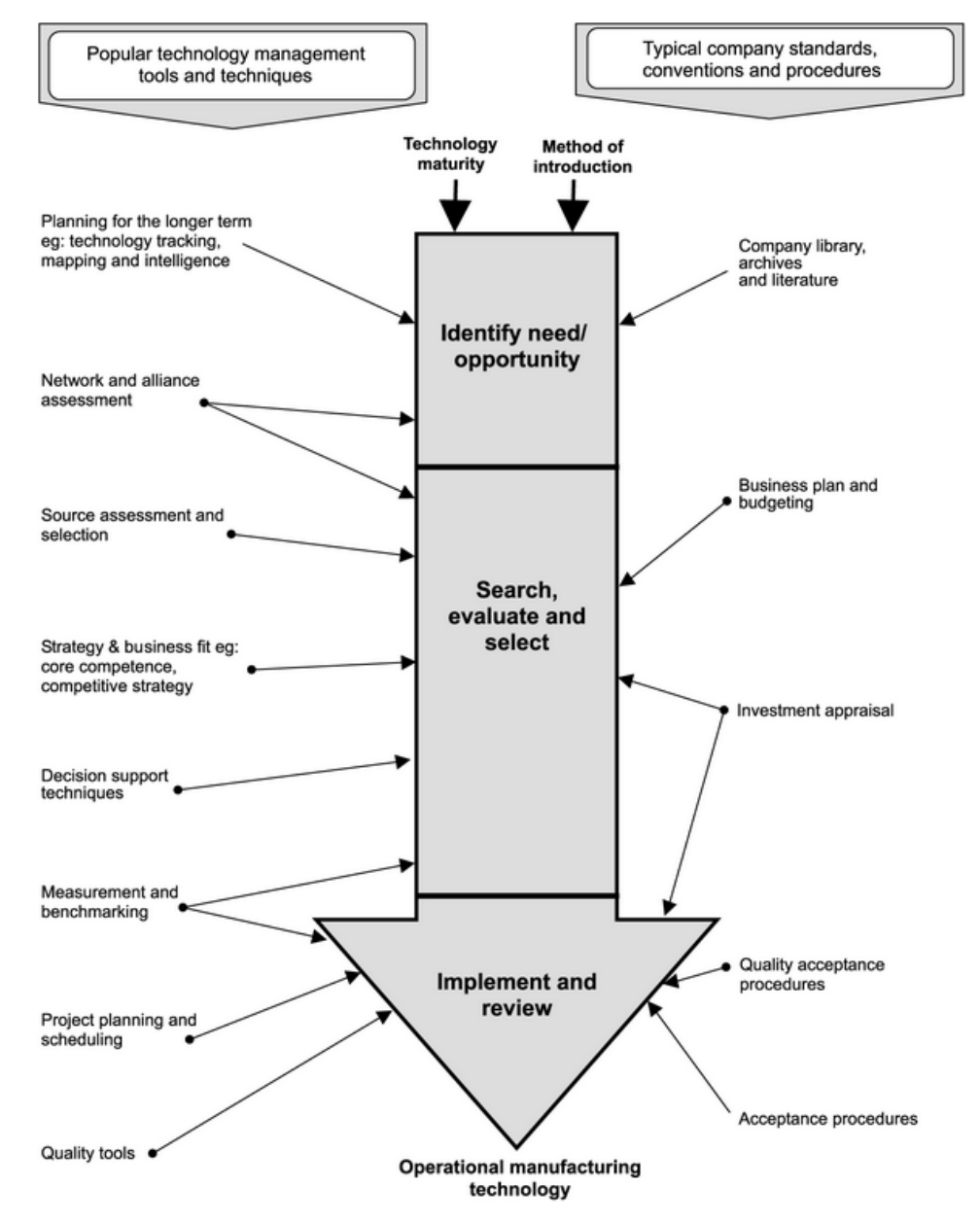

Figure 1 Typical relationships between the integrated process and existing techniques and company procedures 


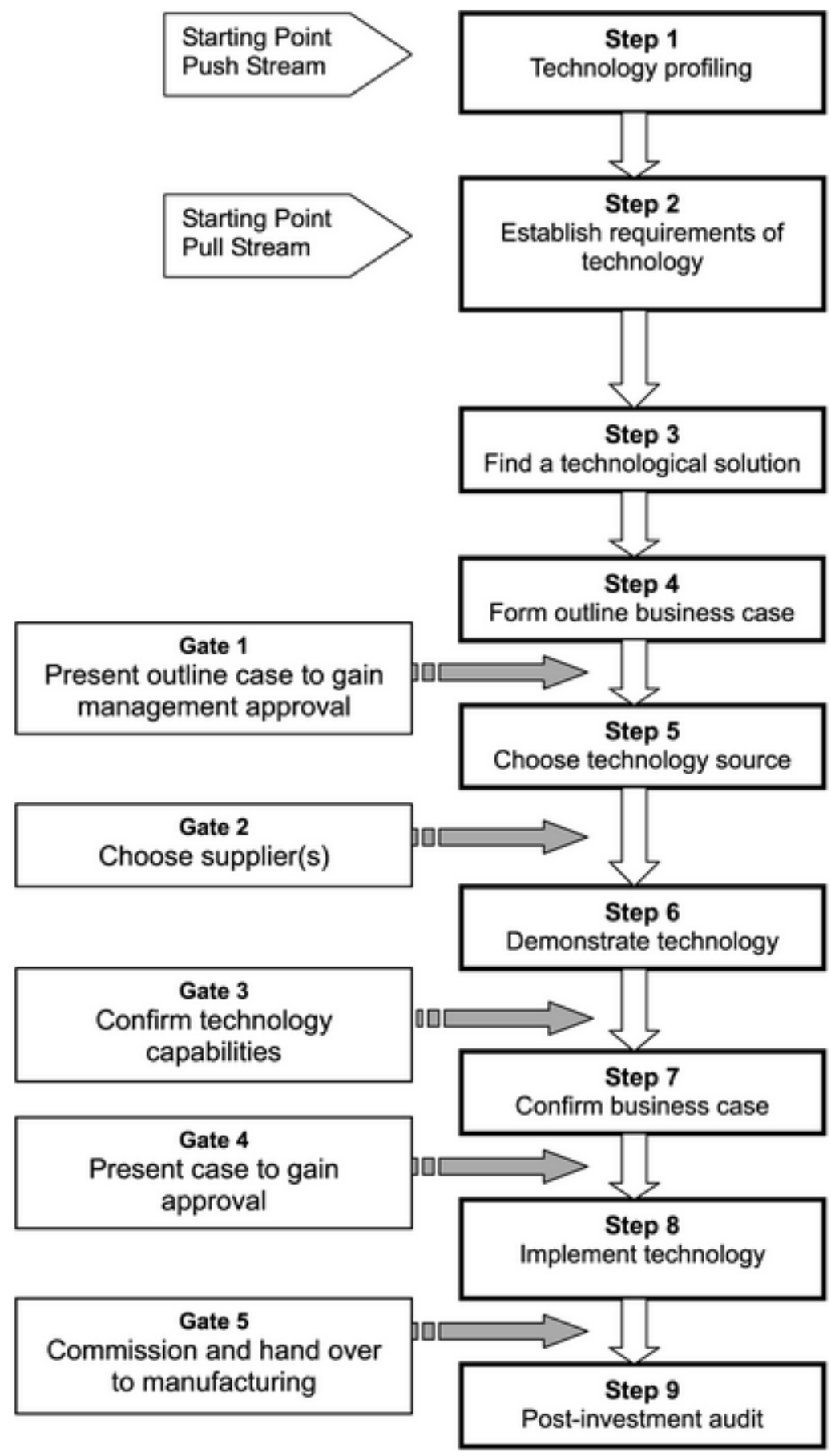

Figure 2 Summary of the manufacturing technology acquisition process 


\begin{tabular}{rll}
\hline Number & Description & Location \\
\hline 1 & Products for healthcare professionals & Leioestershire \\
2 & Precision engineering & Staffordshire \\
3 & Electronic services for manufacturing & Staffordshire \\
4 & Manufacturer of speciality papers & South East \\
5 & Designer and manufacturer of military equipment & Various sites nationally \\
6 & Printer of monetary products & Essex \\
7 & Oil and gas exploration and production & Greater London \\
8 & Gas assisted moulding equipment & Cheshire \\
9 & Electric motor drives & Powys \\
10 & Pharmaceuticals & Essex \\
11 & Plastics & Yorkshire \\
12 & Ink jet and laser printing & Cambridgeshire \\
13 & Manufacturer of sintered metal components & West Midlands \\
14 & Manufacturer of machine tools & Essex \\
15 & Cigarette filters, bonded fibre oomponents & Buckinghamshire \\
16 & Pharmaceuticals & Various sites nationally \\
17 & Mamufacturer of decorating tools and accessories & Norfolk \\
18 & Electro magnetic testing services and facilities & Worcestershire \\
19 & Excavator manufacturer & Staffordshire \\
20 & Precision engineering & Glouestershire \\
21 & Telecommunication equipment & Various sites nationally \\
22 & Electrical engineering contractors & Various sites nationally \\
23 & Electronics and telecommunications & Bedfordshire \\
24 & Computer hardware and commercial sales & Surrey \\
25 & Supplier of professional lighting & Essex \\
26 & Materials joining technology & Cambridgeshire \\
27 & Manufacturer of X-ray equipment & West Sussex \\
28 & Automotive manufacturer & Cheshire \\
\hline & &
\end{tabular}

Table I Overview of companies studied to investigate leading industrial practice in the UK

\begin{tabular}{|c|c|c|c|c|c|c|c|c|c|c|c|c|c|c|c|}
\hline \multirow[t]{2}{*}{ Role } & \multirow[t]{2}{*}{ Description } & \multirow[t]{2}{*}{ Example } & \multicolumn{2}{|c|}{ Step } & \multicolumn{2}{|c|}{$\begin{array}{c}\text { Step } \\
2\end{array}$} & \multicolumn{2}{|c|}{$\begin{array}{l}\text { Step } \\
3\end{array}$} & \multirow[t]{2}{*}{$\begin{array}{c}\text { Step } \\
4\end{array}$} & Step & \multirow[t]{2}{*}{$\begin{array}{c}\text { Step } \\
6\end{array}$} & \multirow[t]{2}{*}{$\begin{array}{c}\text { Step } \\
7 \\
\end{array}$} & \multicolumn{2}{|c|}{ Step } & \multirow[t]{2}{*}{$\begin{array}{c}\text { Step } \\
9\end{array}$} \\
\hline & & & 1 & 2 & 1 & 23 & \begin{tabular}{l|l|} 
& 1 \\
\end{tabular} & 2 & & \begin{tabular}{l|l}
1 & 2
\end{tabular} & & & 1 & 2 & \\
\hline Project leader & $\begin{array}{l}\text { People that drive, own and facilitate the } \\
\text { methodology of technology acquisition }\end{array}$ & $\begin{array}{l}\text { Technology } \\
\text { owner }\end{array}$ & & & & & & & & & & & & & \\
\hline Customer & $\begin{array}{l}\text { People who will directly benefit from } \\
\text { the project, and probably will be } \\
\text { responsiblo for the tochnology in } \\
\text { operation. }\end{array}$ & $\begin{array}{l}\text { Business Unit } \\
\text { Managers }\end{array}$ & & & & & & & & & & & & & \\
\hline $\begin{array}{l}\text { Technology } \\
\text { provider }\end{array}$ & $\begin{array}{l}\text { People who will provide the physical } \\
\text { equipment \& machinery, may be } \\
\text { internal of external to the organisation. }\end{array}$ & $\begin{array}{l}\text { Machine tool } \\
\text { supplier }\end{array}$ & & & & & & & & & & & & & \\
\hline Champion & $\begin{array}{l}\text { People that have a holistic view of the } \\
\text { business. They also have the } \\
\text { capability to influence decisions and } \\
\text { give high level support to the project. }\end{array}$ & $\begin{array}{l}\text { Senior } \\
\text { management }\end{array}$ & & & & & & & & & & & & & \\
\hline $\begin{array}{l}\text { Manufacturing } \\
\text { process } \\
\text { specialists }\end{array}$ & $\begin{array}{l}\text { People who understand the existing } \\
\text { manufacturing procoss, probably } \\
\text { internal to the organisation. }\end{array}$ & $\begin{array}{l}\text { Engineering } \\
\text { team }\end{array}$ & & & & & & & & & & & & & \\
\hline $\begin{array}{l}\text { Technical } \\
\text { specialist }\end{array}$ & $\begin{array}{l}\text { People with indepth knowledge of the } \\
\text { technology being investigated. }\end{array}$ & $\begin{array}{l}\text { Engineering } \\
\text { team consultants }\end{array}$ & & & & & & & & & & & & & \\
\hline Technology guru & $\begin{array}{l}\text { People who specialise in gaining a } \\
\text { wide and extensive knowledge of } \\
\text { technologios. }\end{array}$ & $\begin{array}{l}\text { Engineering. } \\
\text { R\&D staff, } \\
\text { consultants }\end{array}$ & & & & & & & & & & & & & \\
\hline Business advisor & $\begin{array}{l}\text { People from whom appraisal is needed } \\
\text { for the methodology to proceed. }\end{array}$ & $\begin{array}{l}\text { Designers, } \\
\text { marketers }\end{array}$ & & & & & & & & & & & & & \\
\hline Gatekeeper & $\begin{array}{l}\text { People from whom appraisal is needed } \\
\text { for the methodology to proceed. }\end{array}$ & $\begin{array}{l}\text { Director - board } \\
\text { executive }\end{array}$ & & & & & & & & & & & & & \\
\hline
\end{tabular}

Table II Allocation of practitioner roles to steps within the manufacturing technology acquisition process 
I 1 Maintain a knowledge base To increase the knowledge about existing technologies, capacity of the host their capabilities and characteristics organisation to ensure all technological opportunities are exploited

2 Identify situations within the manufacturing operation of the organisation, where new techmologies may provide an opportunity to improve business performance The technology portfolio represents potential opportunities to improve manufacture and enhance business performance.

Action is needed to see.

Identification of possible manufacturing process improvements

seek and design identify where such technologies could be exploited

21 Form a succinct but general

description of the manufacturing To clarify what is needed of A short written definition of improvement sought a technology in quite the outline competitive need general terms, so to form a starting point for the following steps, and to help the organisation understand what the project is setting out to achieve

\begin{tabular}{|c|c|c|c|c|}
\hline $\begin{array}{l}\text { Process } \\
\text { steps }\end{array}$ & Task & What & Why & Outcome \\
\hline & 2 & $\begin{array}{l}\text { Based on the outline } \\
\text { competitive need, ensure } \\
\text { that a complete and fully } \\
\text { informed project team is } \\
\text { brought together for the } \\
\text { project }\end{array}$ & $\begin{array}{l}\text { People are key to success. } \\
\text { The people involved must } \\
\text { be carefully selected from a } \\
\text { range of departments and } \\
\text { functions from within the } \\
\text { business so as to bring } \\
\text { together a wide range of } \\
\text { experience, skills and } \\
\text { knowledge necessary for } \\
\text { suocess }\end{array}$ & $\begin{array}{l}\text { Project team with defined } \\
\text { roles and responsibilities }\end{array}$ \\
\hline & 3 & $\begin{array}{l}\text { A full and in-depth analysis } \\
\text { of the improvement to } \\
\text { manufacturing sought }\end{array}$ & $\begin{array}{l}\text { It is critical that the team } \\
\text { fully understands what is } \\
\text { being attempted, and also to } \\
\text { ensure that all aspects of the } \\
\text { competitive need have been } \\
\text { identified }\end{array}$ & $\begin{array}{l}\text { A detailed statement of the } \\
\text { competitive need in terms of } \\
\text { market based and/or } \\
\text { organisational } \\
\text { improvements sought }\end{array}$ \\
\hline \multirow[t]{2}{*}{3} & 1 & $\begin{array}{l}\text { Search for possible } \\
\text { technology solutions to fulfil } \\
\text { the competitive need of the } \\
\text { organisation }\end{array}$ & $\begin{array}{l}\text { A competitive need has been } \\
\text { identified, a wide range of } \\
\text { possible technologies will } \\
\text { need to be considered before } \\
\text { a single technological } \\
\text { solution can be confidently } \\
\text { acquired }\end{array}$ & $\begin{array}{l}\text { A list of possible technology } \\
\text { solutions to the competitive } \\
\text { need }\end{array}$ \\
\hline & 2 & $\begin{array}{l}\text { Choosing the most suitable } \\
\text { technology type to meet the } \\
\text { competitive needs }\end{array}$ & $\begin{array}{l}\text { To find the optimum } \\
\text { technology from the range } \\
\text { of possible solutions } \\
\text { identified }\end{array}$ & $\begin{array}{l}\text { A report about the } \\
\text { technology shortlist. The } \\
\text { report should be supported } \\
\text { by some technology details } \\
\text { and technical specifications, } \\
\text { along with the rationale that } \\
\text { has been adopted to choose } \\
\text { the techmology. }\end{array}$ \\
\hline 4 & & $\begin{array}{l}\text { Construct a preliminary } \\
\text { business case for the chosen } \\
\text { technology solution }\end{array}$ & $\begin{array}{l}\text { On the basis of the } \\
\text { information gathered so far, } \\
\text { a decision needs to be made } \\
\text { about whether or not to } \\
\text { continue with the project. } \\
\text { This task provides the basic } \\
\text { information necessary to } \\
\text { form such a decision }\end{array}$ & $\begin{array}{l}\text { Outline of business case, } \\
\text { including information and } \\
\text { specifications, costs, gains, } \\
\text { risks, deliverables and time } \\
\text { scales }\end{array}$ \\
\hline \multirow[t]{2}{*}{5} & 1 & $\begin{array}{l}\text { Search for internal and } \\
\text { external sources that are } \\
\text { capable of developing the } \\
\text { technology }\end{array}$ & $\begin{array}{l}\text { To ensure that all potential } \\
\text { sources are identified so that } \\
\text { rigorous supplier selection } \\
\text { can be subsequently carried } \\
\text { out }\end{array}$ & $\begin{array}{l}\text { List of feasible technology } \\
\text { sources and associated } \\
\text { details of suppliers }\end{array}$ \\
\hline & 2 & $\begin{array}{l}\text { Assess in detail the } \\
\text { capabilities of the internal } \\
\text { and external technology } \\
\text { sources, and select the } \\
\text { preferred technology } \\
\text { supplier(s) }\end{array}$ & $\begin{array}{l}\text { The technology supplier(s) } \\
\text { need to be chosen }\end{array}$ & $\begin{array}{l}\text { Prioritised short list of } \\
\text { suppliers }\end{array}$ \\
\hline
\end{tabular}




\begin{tabular}{|c|c|c|c|c|}
\hline $\begin{array}{l}\text { Process } \\
\text { steps }\end{array}$ & Task & What & Why & Outcome \\
\hline 6 & & $\begin{array}{l}\text { Undertake evaluation in } \\
\text { order to improve confidence } \\
\text { in technology and supplier } \\
\text { choice }\end{array}$ & $\begin{array}{l}\text { So far the host company } \\
\text { would have limited } \\
\text { exposure to the capabilities } \\
\text { of the proposed technology. } \\
\text { This is the first real } \\
\text { opportunity to be sure that } \\
\text { both the selected technology } \\
\text { and supplier are highly } \\
\text { likely to perform as } \\
\text { expected }\end{array}$ & $\begin{array}{l}\text { Demonstration report } \\
\text { describing technology, } \\
\text { trials, proposed other } \\
\text { demonstrations, and } \\
\text { summarising actual } \\
\text { capabilities }\end{array}$ \\
\hline 7 & & $\begin{array}{l}\text { Construct business } \\
\text { justification by } \\
\text { re-considering technical } \\
\text { capability of the technology } \\
\text { and re-assessing fit with } \\
\text { need }\end{array}$ & $\begin{array}{l}\text { To ensure that the proposed } \\
\text { technology is a sound } \\
\text { business investment }\end{array}$ & Business case report \\
\hline \multirow[t]{2}{*}{8} & 1 & $\begin{array}{l}\text { Develop a plan to efficiently } \\
\text { and effectively guide } \\
\text { technology implementation }\end{array}$ & $\begin{array}{l}\text { Implementation is complex, } \\
\text { there are many issues to } \\
\text { consider and actions to } \\
\text { coordinate. Careful planning } \\
\text { is key to success }\end{array}$ & $\begin{array}{l}\text { The implementation plan, } \\
\text { including documentation as } \\
\text { a Gantt chart, with the } \\
\text { critical path identified }\end{array}$ \\
\hline & 2 & $\begin{array}{l}\text { Execute the implementation } \\
\text { plan }\end{array}$ & $\begin{array}{l}\text { To transfer technology into } \\
\text { production }\end{array}$ & $\begin{array}{l}\text { Technology installed and } \\
\text { operating }\end{array}$ \\
\hline 9 & & $\begin{array}{l}\text { Carry out ongoing } \\
\text { monitoring of the chosen } \\
\text { technology in operation, } \\
\text { check that the actual } \\
\text { performance meets the } \\
\text { expected, and feed back } \\
\text { information to help the } \\
\text { organisation learn from its } \\
\text { experience }\end{array}$ & $\begin{array}{l}\text { Most technology } \\
\text { acquisitions are reliant on } \\
\text { best estimates and informed } \\
\text { judgements of the project } \\
\text { team. It is valuable to } \\
\text { observe the actual } \\
\text { technology in operation, and } \\
\text { to learn from any variances } \\
\text { between predicted and } \\
\text { realised performance. In this } \\
\text { way, the organisation will } \\
\text { improve its competence in } \\
\text { technology acquisition }\end{array}$ & $\begin{array}{l}\text { Report of real behaviour of } \\
\text { the manufacturing system } \\
\text { and action plan if there are } \\
\text { undesired results. Feedback } \\
\text { for the manufacturing } \\
\text { technology acquisition } \\
\text { process }\end{array}$ \\
\hline
\end{tabular}

Table Al An overview of the content of each step in the manufacturing technology acquisition process

\section{References}

Abernathy, W.J., Utterback, J.M. (1978), "Patterns of industrial innovation", Technology Review, Vol. 80 No.7, pp.4052.

(1997), in Anderson, J., Fears, R., Taylor, B. (Eds),Managing Technology for Competitive Advantage, Cartermill International/Financial Times Healthcare, London.

Armistead, C.G., Mapes, J. (1993), "The impact of supply chain integration on operating performance", Logistics Information Management, Vol. 6 No.4, pp.9-15.

Arnold, G.W., Floyd, M.C. (1997), "Reengineering the new product introduction process", International Journal of Production Economics, Vol. 52 pp.179-83.

Baines, T.S., Darlow, N. (2000), "Mapping the manufacturing technology acquisition process", Manchester, 33rd International MATADOR Conference.

Baines, T.S., Kay, J.M. (2002), "Human performance modelling as an aid in the process of manufacturing system design: a pilot study", International Journal of Production Research, Vol. 40 No.10, pp.2321-34.

Baines, T.S., Whitney, D.E., Fine, C. (1999), "Manufacturing technology sourcing practices in the USA", International Journal of Production Research, Vol. 37 No.4, pp.939-56.

Barker, D., Smith, D.J.H. (1995), "Technology foresight using road-maps", Long Range Planning, Vol. 28 No.2, pp.21-8. Berry, M.M.J., Taggart, J.H. (1998), "Combining technology strategy in small high tech firms", Research Policy, Vol. 26 pp.883-95. 
Bowers, J.L., Christensen, C.M. (1995), "Disruptive technologies: catching the wave", Harvard Business Review, Vol. 73 No.1, pp.43-54.

Cagliano, R., Chiesa, V., Manzini, R. (2000), "Differences and similarities in managing technological collaborations in research, development and manufacturing: a case study", Journal of Engineering and Technology Management, Vol. 17 No.2, pp.193-224.

Chatterji, D. (1996), "Accessing external sources of technology", Research Technology Management, Vol. 39 No.2, pp.48-57.

Chiesa, V., Manzini, R. (1998), "Towards a framework for dynamic technology strategy", Technology Analysis and Strategic Management, Vol. 10 No.1, pp.111-29.

Cohn, S.F. (1980), "Industrial product adoption in a technology push industry", Industrial Marketing Management, Vol. 9 pp.89-95.

Cooke, S., Slack, N. (1991), Making Management Decisions, 2nd ed., Prentice-Hall, Hemel Hempstead.

Drejer, A., Sorensen, S. (2002), "Succeeding with sourcing of competencies in technology-intensive industries", Benchmarking, Vol. 9 No.4, pp.388-409.

Durrani, T.S., Forbes, S.M., Broadfoot, C., Carrie, A.S. (1998), "Managing the technology acquisition process", Technovation, Vol. 18 No.8/9, pp.523-8.

Ealey, L. (1992), "The 'methods' of a quality master", The McKinsey Quarterly, No.4, pp.3-17.

Farrukh, C.J.P., Phaal, R., Probert, D.R. (2000), Technology Management Assessment Procedure - A Guide for Supporting Technology Management in Business, IEE, Stevenage.

Fine, C.H., Whitney, D.E. (1996), "Is the make-buy decision process a core competence?", working paper, Sloan School of Management, MIT, Boston, MA.

Floyd, C. (1997), Managing Technology for Corporate Success, Aldershot, Gower.

Frohlich, M. (1998), "How do you successfully adopt an advanced manufacturing technology?", European Management Journal, Vol. 16 No.2, pp.151-9.

Gerwin, D., Kolodny, H.F. (1992), Management of Advanced Manufacturing Technology: Strategy, Organisation, and Innovation, Wiley, New York, NY.

Gomes-Casseres, B. (1994), "Group versus group: how alliance networks compete", Harvard Business Review, JulyAugust.

Goodman, R.A., Lawless, M.W. (1994), Technology and Strategy: Conceptual Models and Diagnostics, Oxford University Press, New York, NY.

Grandori, A., Soda, G. (1995), "Interfirm networks: antecedents, mechanisms and forms", Organizations Studies, Vol. 16 No.2.

Gregory, M.J., Probert, D.R., Cowell, D.R. (1996), "Auditing technology management processes", International Journal of Technology Management, Vol. 12 No.3, pp.306-19.

Gunter, B.H. (1989), "The use and abuse of Cpk", Quality Progress: Statistics Corner. 
Hakannson, H. (1990), "Technology collaborations in industrial networks", European Management Journal, Vol. 8 No.3, pp.371-9.

Hamel, G., Heene, A. (1994), Competence-Based Competition, Wiley, Chichester.

Harrold, D. (2003), "How to accelerate commissioning", Control Engineering, Vol. 50 No.6, pp.42-8.

Hax, A.C., No, M. (1992), "Linking technology and business strategies: a methodological approach and an illustration", Working Paper 3383-92BPS, Sloan School of Management, MIT, Boston, MA.

Howells, J. (1997), "Rethinking the market - technology relationship for innovation", Research Policy, Vol. 25 pp.1209-19.

Jennings, D. (1997), "Strategic guidelines for outsourcing decisions", The Journal of Strategic Change, Vol. 6 pp.85-96.

Kim, B. (2003), "Managing the transition of technology life cycle", Technovation, Vol. 23 pp.372-81.

Lambe, C.J., Spekman, R.E. (1997), "Alliances, external technology acquisition, and discontinuous technological change", Journal of Product Innovation Management, Vol. 14 pp.102-16.

Luong, L.H.S. (1998), "A decision support system for the selection of computer-integrated manufacturing technologies", Robotics and Computer-Integrated Manufacturing, Vol. 14 pp.45-53.

Mclvor, R. (2000), "A practical framework for understanding the outsourcing process", Supply Chain Management, Vol. 5 No.1, pp.22.

Maylor, H. (2001), "Beyond the Gantt chart: project management moving on", European Management Journal, Vol. 19 No.1, pp.92-100.

Millson, M.R., Raj, S.P., Wilemon, D. (1996), "Strategic partnering for developing new products", Research and Technology Management, May-June, pp.41-9.

Mintzberg, H., Raisinghani, D., Theoret, A. (1976), "The structure of unstructured decision processes", Administrative Science Quarterly, Vol. 21 pp.246-75.

Mohanty, R.P., Deshmukh, S.G. (1998), "Advanced manufacturing technology selection: a strategic model for learning and evaluation", International Journal of Production Economics, Vol. 55 No.3, pp.295.

Mowever, D., Rosenberg, N. (1979), "The influence of market demand upon innovation: a critical review of some recent empirical studies", Research Policy, Vol. 8 No.2, pp.102-53.

Pearn, W.L., Chen, K.S. (1999), "Making decisions in assessing process capability index Cpk", Quality and Reliability Engineering International, Vol. 15 pp.321-6.

Petroni, G. (1985), "Who should plan technological innovation?", Long Range Planning, Vol. 18 No.5, pp.108-15.

Phaal, R., Farrukh, C.J.P., Probert, D.R. (2003), "Technology road-mapping - a planning framework for evolution and revolution", Technological Forecasting and Social Change, Vol. 71 No.1, pp.5-26.

Platts, K.W. (1993), "A process approach to researching manufacturing strategy", International Journal of Operations \& Production Management, Vol. 13 No.8, pp.4-18.

Platts, K.W., Gregory, M.J. (1990), "Manufacturing audit in the process of strategy formulation", International Journal of Operations \& Production Management, Vol. 10 No.9, pp.5-27. 
Popper, E.T., Buskirk, B.D. (1992), "Technology life cycles in industrial markets", Industrial Marketing Management, Vol. 21 No.1, pp.23-32.

Porter, M.E. (1985), Competitive Advantage - Creating and Sustaining Superior Performance, The Free Press, New York, NY.

Preece, D.A. (1989), Managing the Adoption of New Technology, Routledge, London.

Punniyamoorthy, M., Ragavan, P.J. (2003), "A strategic decision model for the justification of technology selection", International Journal of Advanced Manufacturing Technology, Vol. 21 pp.28-72.

Quinn, J.B., Hilmer, F.G. (1994), "Strategic outsourcing", Sloan Management Review, pp.43-55.

Ramasesh, R.V., Jayakumar, M.D. (1993), "Economic justification of advanced manufacturing technology", International Journal of Management Science, Vol. 21 No.3, pp.289-306.

Ranft, A.L., Lord, M.D. (2002), "Acquiring new technologies and capabilities: a grounded model of acquisition implementation", Organization Science, Vol. 13 No.4, pp.420-41.

Robinson, S. (1994), "Simulation projects: building the right conceptual model", Industrial Engineering, Vol. 26 No.9, pp.34-7.

Skinner, W. (1985), Manufacturing - the Formidable Competitive Weapon, Wiley, New York, NY.

Swamidass, P.M. (1987), "Planning for manufacturing technology", Long Range Planning, Vol. 20 No.5.

Twiss, B. (1986), Managing Technological Innovation, 3rd ed., Pitman, London.

Twiss, B., Goodridge, M. (1989), Managing Technology for Competitive Advantage, Pitman, London.

Whipp, R., Rosenfield, P., Pettigrew, A.M. (1991), "Managing the twin processes of competition and change", in Lorange, P. (Eds), Implementing Strategic Process, Change, Learning and Co-operation, Blackwell Business, Oxford.

Yin, R.K. (1994), Case Study Research: Design and Methods, 2nd ed., Sage Publications, London.

Zavecz, T.E. (1997), "Exposure tool purchase decision: evaluation techniques and common pitfalls", Solid State Technology, Vol. 40 pp.97. 